\title{
Kemudahan Prasarana Dalam Pelaksanaan Mata Pelajaran Teknologi Kejuruteraan, Lukisan Kejuruteraan dan Reka Cipta di Sekolah Menengah Harian Malaysia
}

\author{
Mohd Tafizam Mohd Taib, Ramlee Mustapha*
}

Fakulti Pendidikan Teknikal dan Vokasional, Universiti Pendidikan Sultan Idris, 35900 Tanjung Malim, Malaysia

*Corresponding author: dr.ramlee@fptv.upsi.edu.my

\begin{abstract}
Since 1996, technical subjects such as Technology Kejuruteaan (TK), Drawing (LK) and Invention (RC) has been introduced as an elective subject for students grades 4 and Form 5 school newspaper in Malaysia. Examination of the data subjects Lembega TK, LK and RC from 2006 to 2010 showed that students' performance in the Sijil Pelajaran Malaysia (SPM) less favorable. Data Planning and Policy Unit Ministry of Education also showed a decrease in enrollment in kindergarten, LK and RC between 10 to 17 per cent from 2009 to 2011 . Thus, this study is critical to identify the planning and execution of these subjects in terms of infrastructure use some evaluation model KIPP - Context, Input, process and Product (CIPP) by Stufflebeam et al. (1971). So, the purpose of this paper is to report the results of empirical studies conducted on perceptions of administrators and teachers of these subjects to the infrastructure. The data obtained reflect the perceptions of 159 administrators and 176 teachers from various backgrounds, the infrastructure available in secondary schools. Implications and suggestions for teaching and learning are discussed and presented.
\end{abstract}

Keywords: technical subject; infrastructure; KIPP model; day schools; Malaysia

Abstrak

Sejak 1996, mata pelajaran teknikal seperti Teknologi Kejuruteaan (TK), Lukisan Kejuruteraan (LK) dan Reka Cipta (RC) telah diperkenalkan sebagai mata pelajaran elektif kepada pelajar tingkatan 4 dan tingkatan 5 Sekolah Menengah Harian di Malaysia. Data Lembega Peperiksaan untuk mata pelajaran TK, LK dan RC dari 2006 hingga 2010 menunjukkan pencapaian pelajar dalam peperiksaan Sijil Pelajaran Malaysia (SPM) kurang memberangsangkan. Data Unit Perancangan dan Dasar Kementerian Pendidikan juga menunjukkan penurunan enrolmen pelajar TK, LK dan RC diantara 10 ke 17 peratus dari 2009 hingga 2011. Justeru, adalah kritikal kajian ini dijalankan untuk mengenalpasti perancangan dan pelaksanaan mata pelajaran ini dari aspek kemudahan prasarana menggunakan sebahagian model penilaian KIPP-Konteks, Input, Proses dan Produk(KIPP) oleh Stufflebeam et al. (1971). Maka, tujuan kertas kerja ini adalah untuk melaporkan keputusan kajian empirikal yang dijalankan mengenai persepsi pentadbir dan guru mata pelajaran ini terhadap kemudahan prasarana. Data yang diperolehi menggambarkan persepsi 159 orang pentadbir dan 176 orang guru pelbagai latarbelakang, terhadap kemudahan prasarana yang terdapat di sekolah menengah harian. Implikasi dan cadangan terhadap pengajaran dan pembelajaran turut dibincangkan dan dipersembahkan.

Kata kunci: Subjek teknikal; kemudahan prasarana; model KIPP; sekolah harian;Malaysia

C 2017 Penerbit UTM Press. All rights reserved

\subsection{PENGENALAN}

Kemudahan prasarana sekolah merangkumi persekitaran sekolah yang meliputi keadaan keceriaan dan masyarakat sekolah. Keceriaan pula merangkumi pengurusan fizikal termasuklah taman, sudut-sudut pembelajaran, kemudahan istirehat serta pengurusan bahan-bahan dan ABM (Zakaria \& Idris, 1995). Kemudahan prasarana yang baik dapat merangsang guru menggunakan pelbagai sumber yang sesuai untuk membantu mereka menjayakan proses pengajaran dan pembelajaran. Namun kemudahan prasarana sekolah adalah berbeza diantara satu sekolah dengan sekolah yang lain terutama sekali antara sekolah di kawasan bandar dengan sekolah yang terletak di pendalaman (Juraidah, 2005). Kemudahan bukan sahaja untuk tujuan pengajaran dan pembelajaran tetapi merangkumi segala aspek yang ada di persekitaran sekolah, kemudahan ini termasuklah bilik darjah yang kondusif, alat bantu mengajar (ABM), bahan bantu mengajar (BBM), bahan rujukan, bengkel atau makmal dan peralatan bengkel. Persekitaran pembelajaran mata pelajaran teknikal juga mempengaruhi sikap belajar. Justeru menurut Husted et al. (2003) antara kemudahan dan peralatan yang perlu ada ialah, perabot samada yang tetap atau boleh alih serta mesin dan peralatan. 


\subsection{SOROTAN LITERATUR}

Kementerian Pendidikan Malaysia, di dalam laporan “Pembangunan Pendidikan 2001-2010” menyatakan bahawa kemudahan fizikal seperti bilik darjah, makmal, bilik khas, dan kemudahan lain serta persekitarn sekolah yang kondusif dengan proses pendidikan merupakan satu keperluan paling asas bagi menyediakan peluang pembelajaran optimum kepada semua pelajar. Kementerian Pendidikan Malaysia akan berusaha mewujudkan persekitaran yang kondusif, selamat dan selesa di sekolah. Dalam kajian ini pengkaji hanya memfokuskan penilaian dimensi input dari aspek peralatan bengkel dan bahan bantu mengajar (BBM), yang di dapati mempunyai kesan langsung terhadap perlaksanaan mata pelajaran Teknologi Kejuruteraan, Lukisan Kejuruteraan dan Reka cipta di Sekolah Menengah Harian. Menurut Beynon (1997) walaupun intipati pendidikan ialah pembelajaran pelajarnya, elemen-elemen seperti guru, buku teks, teknologi pendidikan, kemudahan fizikal dan sistem pantadbiran semuanya membantu untuk memperkembang dan mempercepatkan proses pembelajaran. Umum berpendapat, hubungan antara persekitaran fizikal yang selesa dengan pembelajaran adalah perlu untuk memastikan para pelajar boleh memberi tumpuan dalam pengajian mereka. Oleh itu, kekurangan aspek-aspek seperti yang dinyatakan, dilihat boleh menjejaskan pembelajaran pelajar.

Kajian Radin (2008) menunjukkan peralatan yang tidak mencukupi dan pelajar berkongsi peralatan untuk melakukan amali kerja kursus Teknologi Kejuruteraan. Maka sudah tentu menyukarkan guru untuk membuat pentaksiran dan pelajar tidak dapat membuat kerja kursus dengan baik dan teratur. Ramai dalam kalangan pelajar akan mengambil masa yang agak lama untuk menyiapkan projek disebabkan kekurangan peralatan bengkel. Antara cadangan dikemukakan UNESCO berkaitan Pendidikan Teknik dan Vokasional pada 2001 ialah memastikan mesin dan peralatan yang digunakan di bengkel institusi pendidikan seharusnya sentiasa di naik taraf mengikut perkembangan, dan pelajar seharusnya berupaya untuk mengendali dan menyelenggara peralatan tersebut. Menurut Syed Kamarudin (2007) wujud hubungan yang signifikan terhadap pengaruh kemudahan pengajaran dan pembelajaran terhadap pencapaian akademik pelajar. Laporan kajian pengesanan graduan UKM juga memberi jawapan memuaskan terhadap kemudahan infrastruktur seperti perpustakaan, makmal dan bilik-bilik kuliah. Oleh itu kekurangan aspek-aspek seperti bilik darjah untuk pengajaran dan peralatan untuk melaksanakan pengajaran akan mempengaruhi pencapaian pelajar.

Abdul Rahman Arshad (2007) menyatakan, kini bukan sahaja sekolah teknik dan politeknik menawarkan mata pelajaran teknikal tetapi juga sekolah harian seperti mata pelajaran Seni Perusahaan. Semua ini memerlukan bengkel dan makmal, dan bagi memenuhi peningkatan keperluan, perpindahan kemudahan dilakukan. Sementara semua perpindahan kemudahan di terima dalam jangka masa pendek, kemudahan jangka masa panjang yang lebih tersusun perlu disediakan segera. Di antara cabaran yang harus diberi perhatian seperti yang termaktub dalam Pelan Induk Pembangunan Pendidikan (PIPP) adalah cabaran yang berkaitan dengan keperluan untuk menyediakan infrastruktur fizikal dan bukan fizikal yang berkualiti bagi mencapai objektif teras antaranya (1) Memastikan sekolah mempunyai persekitaran yang kondusif dengan infrastruktur pengajaran dan pembelajaran terbaik, (2) memastikan infrastruktur fizikal yang disediakan adalah fungsional dan berkesan dari segi kos, sumber digunakan secara optimum, penyelenggaraan dibuat secara sistematik, dan kemudahan sedia ada dinaikkan taraf secara berjadual (Kementerian Pelajaran Malaysia, 2006). Kajian Ruhizan et. al (2012) terhadap proses pengajaran dan pembelajaran Lukisan Kejuruteraan juga mendapati kemudahan bilik LK merupakan salah satu permasalahan yang dihadapi oleh guru dan pelajar yang terlibat dalam pelaksanaan mata pelajaran LK.

Bahan bantu mengajar (BBM) ialah sumber maklumat yang digunakan dalam pengajaran, ia adalah tambahan kepada bahan-bahan pengajaran yang asas iaitu buku teks, buku kerja sekolah dan buku nota sekolah. Bahan-bahan tambahan ini disalurkan kepada pelajar melalui media tambahan iaitu media elektronik dan media cetak. Finch \& Crunkilton (2005) menjelaskan bahan bantu mengajar adalah sumber yang boleh dikategorikan kepada tiga iaitu bahan bercetak, audivisual dan 'manipulative aid'. Bahan-bahan rujukan utama mungkin terdiri daripada satu atau dua jenis sahaja seperti buku teks dan sukatan pelajaran, sebaliknya ada kurikulum yang mencadangkan penggunaan berbagai bahan yang terdiri daripada bahan-bahan untuk pelajar seperti buku teks, buku kerja, buku bacaan tambahan dan buku latihan dan bahan-bahan untuk digunakan oleh guru seperti buku panduan, huraian sukatan pelajaran, buku sumber, carta dan poster (Abu Bakar,1991).

Bahan-bahan bantu mengajar bagi mata pelajaran elektif seperti Teknologi Kejuruteraan, Lukisan Kejuruteraan dan Reka cipta begitu terhad di pasaran menyebabkan pelajar dan guru bergantung sepenuhnya kepada buku teks sahaja. Bahan-bahan pengajaran dan pembelajaran dirancang dan disusun supaya guru dan pelajar mendapat manfaat daripadanya, namun keberkesanannya sukar dibuktikan melainkan setelah dinilai (Abu Bakar, 1991). Fulford (1993) telah menjalankan kajian eksperimen tentang penggunaan 'Compressed Speech Audio' dan penggunaan teks tulisan dan pembelajaran. Keputusan mendapati perbezaan yang signifikan di antara kumpulan rawatan iaitu yang menggunkan 'Compressed Speech Audio' dengan kumpulan kawalan iaitu yang menggunkan teks tulisan dalam pembelajaran. Justeru dalam kajian ini penyelidik ingin melihat apakah bentuk bahan bantu mengajar (BBM) yang disediakan oleh Kementerian Pelajaran Malaysia atau pihak-pihak berkaitan samada dalam bentuk media elektronik atau media cetak bagi kegunaan pelajar ataupun guru, seterusnya menentukan keberkesanannya dalam mata pelajaran Teknologi Kejuruteraan, Lukisan Kejuruteraan dan Reka cipta. Ahmad Zairi (2002) mendapati pelajar sukar mendapatkan bahan rujukan tambahan yang sesuai dipasaran menyebabkan mereka menggunakan buku teks sepenuhnya sebagai rujukan pembelajaran, bahan bantu mengajar (BBM) yang merupakan permasalahan utama yang dihadapi oleh guru semasa mengajar LK dan juga merupakan keperluan utama guru dalam pengajaran dan pembelajaran (Ruhizan et al., 2012)

\subsection{PERNYATAAN MASALAH}

Kemerosotan bilangan pelajar yang mengambil mata pelajaran teknikal yang terdiri daripada mata pelajaran Teknologi Kejuruteraan, Lukisan Kejuruteraan dan Reka cipta sebagai mata pelajaran elektif di Sekolah Menengah Harian, memberi banyak implikasi kepada sistem pendidikan teknik dan vokasional di Malaysia. Sumber Unit Data, Bahagian Perancangan dan Penyelididkan Pendidikan, Kementerian Pendidikan Malaysia, jumlah enrolmen pelajar pada tahun 2009 adalah seramai 42, 540 orang telah merosot kepada 38, 211 orang pada tahun 2010 dan seterusnya pada tahun 2011 jumlah ini merosot lagi kepada 31, 879 orang. Kemerosotan enrolmen pelajar pada tahun 2010 berbanding tahun 2009 adalah sebanyak 10.2\%, kian membimbangkan pada tahun 2011 berbanding 2010 dengan kemerosotan $16.6 \%$. 


\subsection{METODOLOGI KAJIAN}

Reka bentuk kajian ini adalah kajian penilaian program menggunakan sebahagian daripada model Context, Input, Process dan Product (CIPP) oleh Stufflebeam et al. (1971). Oleh kerana responden dalam kajian ini ramai tetapi memerlukan interaksi yang minimum dengan responden, soal selidik sangat sesuai digunakan. Walaupun data yang diperoleh melalui soal selidik dalam kajian ini adalah data numerik dan dianalisis mengikut prosedur statistik secara deskriptif dan inferensi, namun sebahagian daripada data numerik tersebut memerlukan penjelasan lebih mendalam melalui temubual daripada sebilangan kecil responden. Pemerhatian selanjutnya menggunakan senarai semak juga dijalankan bagi melihat secara umum proses pengajaran dan pembelajaran melalui lawatan ke sekolah. Kajian ini adalah untuk meninjau kelemahan dan kekuatan aspek kemudahan prasarana dalam pelaksanaan mata pelajaran, tiada teori khusus yang diuji atau dihasilkan. Kaedah kuantitatif sesuai digunakan untuk mengukur pembolehubah dan menguji hipotesis kajian bagi memperoleh data numerik tetapi data numerik tidak dapat menjelaskan pemahaman lebih mendalam tentang suatu konteks. Bagi memenuhi tujuan tersebut, Gay \& Airasian (2000) dan Neuman (2000) menjelaskan kedua-dua kaedah kuantitatif dan kualitatif sesuai dilaksanakan dalam sesuatu kajian.

Populasi dan sampel kajian ini dipilih dari 95 buah sekolah bagi mata pelajaran Teknologi Kejuruteraan, 323 buah sekolah bagi mata pelajaran Lukisan Kejuruteraan dan 222 buah sekolah bagi mata pelajaran Reka Cipta di Semenanjung Malaysia. Sekolah-sekolah tersebut dibahagikan mengikut lima zon iaitu zon utara (Perlis, Kedah dan Pulau Pinang), zon barat (Perak), zon tengah (Selangor, Kuala Lumpur dan Negeri Sembilan), zon selatan (Melaka dan Johor) dan zon timur (Pahang, Terengganu dan Kelantan). Namun demikian hanya dua puluh dua buah sekolah dipilih daripada setiap zon. Bagi memastikan pulangan yang tidak kurang daripada $\mathrm{n}=335$ (Krejcie \& Morgan, 1970), maka sebanyak 408 sampel kajian dipilih secara rawak strata mengikut zon yang terdiri daripada pengetua, penolong kanan akademik, guru kanan mata pelajaran, guru Teknologi Kejuruteraan, guru Lukisan Kejuruteraan, dan guru Reka cipta. Seramai 12 orang responden yang terdiri daripada 6 orang pentadbir dan 6 orang guru yang sedang mengikuti mata pelajaran Teknologi Kejuruteaan, Lukisan Kejuruteaan dan Reka Cipta di Sekolah Menengah Harian telah ditemubual. Instrumen soal selidik, protokol temu bual dan senarai semak pemerhatian dibina sendiri dengan mematuhi langkah-langkah pembinaan instrumen seperti kajian rintis, kesahan dan kebolehpercayaan. Instrumen soal selidik dibina terlebih dahulu kemudian dijalankan kajian rintis. Maklumat kajian rintis soal selidik dijadikan asas untuk membina instrumen pemerhatian. Seterusnya maklumat daripada kajian rintis, instrumen soal selidik dan pemerhatian pula dijadikan asas untuk membina protokol temu bual.

\subsection{DAPATAN KAJIAN}

\section{Dapatan Soal Selidik}

Skor min kemudahan prasarana bagi pentadbir dan guru ditunjukkan seperti dalam Jadual 1. Skor min kemudahan prasarana daripada pentadbir adalah setuju iaitu 3.86, manakala skor min guru pula adalah juga setuju iaitu 3.59. Ini menunjukkan skor min pentadbir terhadap kemudahan prasarana adalah lebih tinggi jika dibandingkan dengan skor min guru.

Jadual 1 Skor min kemudahan prasarana dalam kalangan pentadbir dan guru

\begin{tabular}{|c|c|c|c|c|c|c|}
\hline & \multicolumn{3}{|c|}{$\begin{array}{c}\text { Pentadbir } \\
(\mathrm{n}=159)\end{array}$} & \multicolumn{2}{c|}{$\begin{array}{c}\text { Guru } \\
(\mathrm{n}=176)\end{array}$} \\
\hline & Skor min & Sisihan Piawai & Interpretasi skor min & Skor min & Sisihan Piawai & Interpretasi skor min \\
\hline Kemudahan prasarana & 3.86 & 0.52 & Setuju & 3.59 & 0.60 & Setuju \\
\hline
\end{tabular}

Ujian-t dijalankan bagi melihat perbezaan persepsi pentadbir dan guru terhadap kemudahan prasarana. Jadual 2, menunjukkan kemudahan prasarana mempunyai nilai $p=0.00$ dan signifikan pada paras 0.05 . Oleh itu, terdapat perbezaan yang signifikan di antara persepsi pentadbir dengan persepsi guru mengenai kemudahan prasarana.

Jadual 2 Ujian-t skor min kemudahan prasarana di kalangan pentadbir dan guru

\begin{tabular}{|c|c|c|c|c|}
\hline & $\mathrm{N}$ & Darjah kebebasan & $\mathrm{t}$ & Signifikan (2-hujung) $(p)$ \\
\hline Kemudahan prasarana & 335 & 333 & 4.39 & $0.00 *$ \\
\hline
\end{tabular}

Untuk menjelaskan lebih lanjut tentang perbezaan persepsi pentadbir dan guru terhadap kemudahan prasarana, skor min untuk peralatan bengkel dan bahan bantu mengajar ditunjukkan dalam Jadual 3. Skor min keseluruhan peralatan bengkel ialah 3.86, manakala skor min keseluruhan bahan bantu mengajar ialah 3.48. Pada keseluruhannya pentadbir dan guru mempunyai skor min setuju terhadap peralatan bengkel dan bahan bantu mengajar namun pada skor min yang lebih rendah berbanding peralatan bengkel dan menghampiri tidak pasti.

Jadual 3 Skor min keseluruhan peralatan bengkel dan bahan bantu mengajar

\begin{tabular}{|c|c|c|c|}
\hline & Skor min keseluruhan & Sisihan piawai & Interprestasi skor min \\
\hline Peralatan bengkel & 3.86 & 0.65 & Setuju \\
\hline Bahan bantu mengajar & 3.48 & 0.70 & Setuju \\
\hline
\end{tabular}


Untuk perbincangan lebih lanjut Jadual 4, pula menunjukkan perbezaan skor min bagi peralatan bengkel dan bahan bantu mengajar antara pentadbir dan guru iaitu dua elemen dalam komponen kemudahan prasarana pembolehubah input yang di tetapkan dalam penyelidikan ini. Skor min bagi peralatan bengkel dan bahan bantu mengajar di kalangan pentadbir adalah pada tahap lebih tinggi jika dibandingkan dengan guru. Skor min peralatan bengkel bagi pentadbir adalah 3.96 dan guru pula 3.77. Skor min bahan bantu mengajar bagi pentadbir adalah 3.69 dan guru pula 3.28. Pada keseluruhannya pentadbir mempunyai skor yang setuju terhadap peralatan bengkel, juga setuju terhadap bahan bantu mengajar namun pada skor min yang lebih rendah berbanding perlatan bengkel dan menghampiri tidak pasti. Manakala guru mempunyai skor min yang setuju terhadap peralatan bengkel, tetapi tidak pasti terhadap bahan bantu mengajar.

Jadual 4 Skor min peralatan bengkel dan bahan bantu mengajar dalam kalangan pentadbir dan guru

\begin{tabular}{|c|c|c|c|c|}
\hline & \multicolumn{2}{|c|}{ Pentadbir $(\mathrm{n}=159)$} & \multicolumn{2}{c|}{ Guru $(\mathrm{n}=176)$} \\
\hline & Skor min & Interprestasi skor min & Skor min & Interpretasi skor min \\
\hline Peralatan bengkel & 3.96 & Setuju & 3.77 & Setuju \\
\hline Bahan bantu mengajar & 3.69 & Setuju & 3.28 & Tidak pasti \\
\hline
\end{tabular}

Setelah ujian-t dijalankan, Jadual 5 menunjukkan tidak terdapat perbezaan yang signifikan antara persepsi pentadbir dan guru bagi peralatan bengkel kerana nilai $\mathrm{p}=0.07$ adalah lebih kecil daripada nilai $\mathrm{p}=0.05$. Terdapat perbezaan yang signifikan antara persepsi pentadbir dan guru bagi bahan bantu mengajar di mana nilai $\mathrm{p}=0.00$ adalah lebih kecil daripada nilai $\mathrm{p}=0.05$.

Jadual 5 Ujian-t ke atas skor min peralatan bengkel dan bahan bantu mengajar

\begin{tabular}{|c|c|c|c|c|}
\hline Komponen Input & $\mathrm{n}$ & Darjah Kebebasan & $\mathrm{t}$ & Signifikan (2-hujung) \\
\cline { 1 - 3 } Peralatan bengkel & \multirow{2}{*}{335} & 333 & 2.69 & 0.07 \\
\cline { 1 - 3 } Bahan bantu mengajar & & & 5.58 & $0.00 *$ \\
\hline
\end{tabular}

Sebagai penjelasan lebih lanjut mengenai persepsi pentadbir dan guru terhadap peralatan bengkel dan bahan bantu mengajar, skor min peralatan bengkel dan bahan bantu mengajar dibincangkan mengikut mata pelajaran berdasarkan Jadual 6. Skor min peralatan bengkel adalah setuju iaitu 3.86 dalam mata pelajaran Teknologi Kejuruteraan dan setuju iaitu 3.83 dalam mata pelajaran Lukisan Kejuruteraan juga setuju iaitu 3.92 dalam mata pelajaran Reka Cipta. Skor min bahan bantu mengajar adalah setuju iaitu 3.41 dalam mata pelajaran Teknologi Kejuruteraan dan setuju iaitu 3.59 dalam mata pelajaran Lukisan Kejuruteraan juga setuju iaitu 3.42 dalam mata pelajaran Reka Cipta, namun skor min bahan bantu mengajar bagi ketiga-tiga mata pelajaran amat menghampiri tahap tidak pasti. Secara amnya, skor min pentadbir dan guru terhadap peralatan bengkel adalah lebih tinggi berbanding skor min terhadap bahan bantu mengajar dalam ketiga-tiga mata pelajaran ini.

Jadual 6 Skor min peralatan bengkel dan bahan bantu mengajar mengikut mata pelajaran

\begin{tabular}{|c|c|c|c|c|c|c|c|c|c|}
\hline & \multicolumn{9}{|c|}{ Mata Pelajaran } \\
\hline & \multicolumn{3}{|c|}{ Teknologi Kejuruteraan $(n=125)$} & \multicolumn{3}{|c|}{ Lukisan Kejuruteraan $(n=127)$} & \multicolumn{3}{|c|}{$\operatorname{Reka} \operatorname{Cipta}(\mathrm{n}=83)$} \\
\hline Pembolehubah bersandar & Min & $\begin{array}{l}\text { Sisihan } \\
\text { Piawai }\end{array}$ & $\begin{array}{l}\text { Interpretasi skor } \\
\text { min }\end{array}$ & Min & $\begin{array}{l}\text { Sisihan } \\
\text { Piawai }\end{array}$ & $\begin{array}{l}\text { Interpretasi skor } \\
\text { min }\end{array}$ & Min & $\begin{array}{l}\text { Sisihan } \\
\text { Piawai }\end{array}$ & $\begin{array}{l}\text { Interpretasi skor } \\
\text { min }\end{array}$ \\
\hline Peralatan bengkel & 3.86 & 0.63 & Setuju & 3.83 & 0.74 & Setuju & 3.92 & 0.53 & Setuju \\
\hline Bahan bantu mengajar & 3.41 & 0.65 & Setuju & 3.59 & 0.70 & Setuju & 3.42 & 0.74 & Setuju \\
\hline
\end{tabular}

ANOVA dijalankan bagi menjelaskan perbezaan persepsi mengenai peralatan bengkel dan bahan bantu mengajar di kalangan pentadbir dan guru mengikut mata pelajaran. Jadual 7 menunjukkan tidak terdapat perbezaan yang signifikan antara persepsi pentadbir dan guru bagi peralatan bengkel kerana nilai $\mathrm{p}=0.63$ adalah lebih besar daripada nilai $\mathrm{p}=0.05$. Tidak terdapat perbezaan yang signifikan antara persepsi pentadbir dan guru bagi bahan bantu mengajar di mana nilai $p=0.09$ adalah lebih besar daripada nilai $p=0.05$. Ini menggambarkan tidak terdapatnya perbezaan persepsi pentadbir dan guru terhadap peralatan bengkel dan bahan bantu mengajar mengikur mata pelajaran dalam pelaksanaan mata pelajaran Teknologi Kejuruteraan, Lukisan Kejuruteraan dan Reka Cipta di Sekolah Menengah Harian.

Jadual 7 ANOVA peralatan bengkel dan bahan bantu mengajar mengikut mata pelajaran

\begin{tabular}{|c|c|c|}
\hline Pembolehubah bersandar & $\mathrm{F}$ & Signifikan $(p)$ \\
\hline Peralatan bengkel & 0.85 & 0.63 \\
\hline Bahan bantu mengajar & 2.43 & 0.09 \\
\hline
\end{tabular}

Bagi menghuraikan dengan lebih lanjut persepsi guru yang berada pada tahap tidak pasti terhadap bahan bantu mengajar, skor min guru terhadap bahan bantu mengajar mengikut mata pelajaran di dibincangkan dalam Jadual 8. Skor min guru Teknologi Kejuruteraan 
terhadap bahan bantu mengajar adalah positif tidak pasti iaitu 3.24, skor min guru Lukisan Kejuruteraan pula adalah setuju yang amat rendah iaitu 3.43, manakala skor min guru Reka Cipta juga adalah tidak pasti iaitu 3.11. Secara keseluruhannya persepsi guru Lukisan Kejuruteraan adalah lebih positif berbanding persepsi guru Teknologi Kejuruteraan, dan persepsi guru Teknologi Kejuruteraan adalah lebih positif berbanding guru Reka Cipta namun keduanya adalah tidak pasti.

Jadual 8 Skor min guru terhadap bahan bantu mengajar mengikut mata pelajaran

\begin{tabular}{|c|c|c|c|c|c|c|c|c|c|}
\hline & \multicolumn{9}{|c|}{ Mata Pelajaran } \\
\hline & \multicolumn{3}{|c|}{ Teknologi Kejuruteraan $(n=71)$} & \multicolumn{3}{|c|}{ Lukisan Kejuruteraan $(n=68)$} & \multicolumn{3}{|c|}{ Reka Cipta $(n=37)$} \\
\hline Pembolehubah bersandar & Min & $\begin{array}{l}\text { Sisihan } \\
\text { Piawai }\end{array}$ & $\begin{array}{c}\text { Interpretasi skor } \\
\text { min }\end{array}$ & Min & $\begin{array}{l}\text { Sisihan } \\
\text { Piawai }\end{array}$ & $\begin{array}{l}\text { Interpretasi skor } \\
\text { min }\end{array}$ & Min & $\begin{array}{l}\text { Sisihan } \\
\text { Piawai }\end{array}$ & $\begin{array}{l}\text { Interpretasi skor } \\
\text { min }\end{array}$ \\
\hline Bahan bantu mengajar & 3.24 & 0.66 & Tidak pasti & 3.43 & 0.76 & Setuju & 3.11 & 0.80 & Tidak pasti \\
\hline
\end{tabular}

Kemudahan prasarana juga dikenalpasti sebagai masalah utama yang dinyatakan pentadbir dan guru dalam soalan terbuka soal selidik seperti masalah kewujudan bengkel khusus untuk mata pelajaran, perbekalan peralatan bengkel, kekangan kemudahan ICT, perisian pembelajaran, stor simpanan, penyelenggaraan peralatan, sistem perbekalan yang tidak sempurna, perabot yang tidak mengikut spesifikasi, pemantauan kemudahan prasarana dan bahan bantu mengajar yang lemah, dan tanggungjawab pihak sekolah terhadap kemudahan yang disediakan.

\section{Dapatan Temubual}

Pandangan dan dapatan dalam aspek kemudahan prasarana. Contoh jawapan yang dikemukakan oleh pentadbir semasa temu bual adalah seperti berikut:

'Ok prasarana.. bengkel memang ada kerusi meja tu adalah, aa..tapi bahagian aa..komputer memang tak..h..hm, nak kata..tak mencapai tahap yang di..di..ha..ya..diharapkan, bila dah dibekalkan awal-awal, lepas tu, aa..tidak ada maintainance, kerosakan tak disambut dengan segera, jadi perkara begitu memang memang membantutkan proses pnp'(PT1LK).

'...begitu juga dengan $R C, R C$ hanya menumpang di bengkel MPV seni reka tanda.....tapi alhamdulillahlah, sebab reka tanda tu lengkap, dari segi bengkel dia lengkap, itu sajalah kemudahan yang boleh digunakan, itu yang saya lihat jugalah, tak ada rasa..aa..apa ni,,kalau bilik dia sendiri dia lebih selesa, berbanding kalau berkongsi dengan orang, dan mungkin, kemungkinan juga, tak tahu apa lagi kemudahan-kemudahan lain yang seharusnya ada di bilik dia, dia hanya bergantung kepada apa yang ada di bilik MPV sahaja'(PT1RC).

'...memang guru-guru ada menggunakan alat bantu mengajarlah, ehm..tetapi alat bantu mengajar tersebut mungkin dah lama, aha..betul, dah lama mungkin sepuluh tahun dulu, jadi benda tu tidak di up gradekan, ehm..jadi bila tak di upgradekan maksunya kita masih menggunakan BBM atau ABM yang lamalah...'(PT1TK).

Pandangan dan dapatan aspek kemudahan prasarana. Contoh jawapan yang dikemukakan oleh guru semasa temu bual adalah seperti berikut:

'Apa yang disediakan sebenarnya, macam tak de tu sanagatlah, tak de guna sangatlah sebab bilik LK pun meja dia tu meja biasa, meja yang tak boleh condong. Tak berapa sesuailah...ha.ah..hmmm...'(G1LK).

'Kalau nak cakap tentang kemudahan prasarana ni, saya terpaksa bercerita secara jujurlah, Ya, kalau nak kira kemudahan dalam bentuk machine dan peralatan dan sebagainya, dia adalah dah terlalu lamalah, dan terlalu teruk dan daif, sebab alat-alat yang digunakan di peringkat sekolah ni, pelajarpelajar tak kan jumpa sekiranya mereka pergi ke kilang-kilang ataupun pusat-pusat industri, jadi ini...lama punya barang, hmm... bahan-bahan dia, alatalat dia, dan yang disediakan di peringkat pasaran nanti benda yang baru yang canggih yang lebih sofisticated'(G2RC).

'Bahan bantu mengajar...memang saya gunakan buku tekslah dan juga power point, ada..aa..apa yang dibagi tu, cd, aa..cd couseware, tapi cd courseware tu tak menepati, sebab macam cd ETEMS jugak kan, bila kita on macam tu benda tak boleh nak stop, ha..ha..jadi saya selesa dengan power point, makna kita boleh kat situ, kita terangkan dan boleh sambung balik'(G2TK).

\section{Dapatan Pemerhatian}

Hasil pemerhatian di Jadual 9, menunjukkan dapatan daripada pemerhatian kemudahan prasarana di sekolah. 12 (66.7\%) buah sekolah mempunyai bengkel, $12(66.7 \%)$ buah sekolah mempunyai stor alatan, 10 (55.6\%) mempunyai CD courseware, 9 (50.0\%) mempunyai alatan tangan dan 7 (38.9\%) mempunyai peralatan mesin. Ini menunjukkan bahawa kemudahan prasarana di sekolah yang menawarkan mata pelajaran Teknologi Kejuruteraan, Lukisan Kejuruteraan dan Reka Cipta masih tidak sempurna dan perlu di ambil perhatian sewajarnya oleh pihak bertanggungjawab. Pemerhatian juga mendapati kemudahan prasarana di sekolah untuk ketiga-tiga mata pelajaran ini memang tidak sempurna dimana, $11(61.1 \%)$ buah sekolah tidak mempunyai peralatan mesin, $9(50.0 \%)$ buah sekolah tidak mempunyai alatan tangan, 8 (44.4\%) tidak mempunyai CD courseware, 6 (33.3\%) tidak mempunyai bengkel dan 6 (33.3\%) tidak mempunyai stor alatan. 
Jadual 9 Analisis pemerhatian ke atas kemudahan prasarana

\begin{tabular}{|c|c|c|c|c|}
\hline \multirow{2}{*}{ Kemudahan Prasarana } & \multicolumn{2}{|c|}{ Ada } & \multicolumn{2}{c|}{ Tiada } \\
\cline { 2 - 5 } & Bilangan & Peratus & Bilangan & Peratus \\
\hline Bengkel & 12 & 66.7 & 6 & 33.3 \\
\hline Alatan tangan & 9 & 50.0 & 9 & 50.0 \\
\hline Peralatan mesin & 7 & 38.9 & 11 & 61.1 \\
\hline Stor alatan & 12 & 66.7 & 6 & 33.3 \\
\hline CD courseware & 10 & 55.6 & 8 & 44.4 \\
\hline
\end{tabular}

\subsection{PERBINCANGAN DAN RUMUSAN}

Kemudahan yang lengkap bagi sesuatu kemahiran yang akan dipelajari adalah satu kemestian. Sesuatu kumpulan latihan tidak boleh mempunyai terlalu ramai pelatih, jumlah yang sesuai mungkin antara 8 hingga 15 orang bagi setiap kumpulan latihan. Manakala kemudahan yang disediakan seperti ruang latihan, ruang belajar, peralatan dan bahan-bahan pembelajaran mestilah untuk jumlah yang ditetapkan (Ahmad Suhaimi, 2006). Namun demikian dalam kajian ini masalah kemudahan prasaranan adalah masalah masalah utama yang disuarakan oleh pentadbir (23.69\%), guru (20.83\%) dan pelajar (23.19\%), dalam soalan terbuka soal selidik. Begitu juga hasil temubual kekerapan respons temubual mengikut konteks kemudahan prasarana adalah antara yang tertinggi bagi pentadbir (12.81\%) dan guru (13.74\%), menunjukkan responden kerap memberi kenyataan tentang kemudahan prasaranan yang bermasalah di sekolah menengah harian. Ini bersamaan dengan dapatan Mohamad Husin (2006) dalam kajiannya menunjukkan bahawa Sekolah Menengah Teknik masih menghadapi kekurangan kemudahan fizikal dan peralatan untuk pelaksanaan pembelajaran konteksual. Dapatan kajian mengenai kekurangan kemudahan prasarana dalam pelaksanaan mata pelajaran teknikal juga disokong oleh dapatan kajian oleh Fazidah (2002) dan Azizah (2003).

Persekitaran pembelajaran mata pelajaran teknikal juga mempengaruhi sikap belajar, justeru menurut Husted et. al (2003) antara kemudahan dan peralatan yang perlu ada ialah, perabot samada yang tetap atau boleh alih serta mesin dan peralatan. Responden soal selidik dan temubual menyatakan masih terdapat sekolah yang tidak mempunyai bengkel, menumpang di begkel MPV atau Kemahiran Hidup, menjalankan pengajaran dan pembelajaran secara teori di bilik darjah dilihat memberi tekanan kepada guru dan pelajar, ini selari dengan kajian oleh Ruhizan et al. (2012) mendapati kemudahan bilik LK merupakan salah satu permasalahan yang dihadapi oleh guru dan pelajar yang terlibat dalam pelaksanaan mata pelajaran LK. Manakala dapatan kajian Bahagian Perancangan dan Penyelidikan Dasar Pendidikan (2006) yang mendapati faktor prasarana turut mempengaruhi kejayaan pelajar.

Penggunaan buku teks atau teori berbantu LCD projektor, guru menayangkan satu-satunya BBM yang ada iaitu ' $C D$ Courseware' yang dikatakan tidak interaktif terhadap pelajar berpencapaian sederhana di sekolah menengah harian, keadaan ini berlaku disebabkan masalah kekurangan bahan rujukan tambahan bagi mata pelajaran di pasaran. Dapatan ini adalah selari dengan kajian Ruhizan et. al (2012) mendapati terdapat beberapa permasalahan dan keperluan utama pelajar dan guru dalam pengajaran dan pembelajaran. Antaranya adalah bahan bantu mengajar (BBM) yang merupakan permasalahan utama yang dihadapi oleh guru semasa mengajar LK dan juga merupakan keperluan utama guru dalam pengajaran dan pembelajaran. Kajian Alias (2010) menunjukkan aspek-aspek seperti bahan rujukan untuk Pendidikan Islam tidak mencukupi dan Zawawi (2008) mendapati kebanyakan bahan bantu mengajar untuk Bahasa Arab Komunikasi di Sekolah Menengah Kebangsaan Agama tidak dibekalkan oleh pihak Kementerian atau pihak sekolah. Begitu juga kajian oleh Rudzi (2003) berkenaan penilaian program diploma kesetiausahaan eksekutif di Universiti Teknologi Mara menunjukkan responden bersetuju bahawa bahan-bahan bercetak seperti buku dan jurnal sangat releven dan membantu proses pembelajaran dalam bidang pengajian yang diikuti tetapi bahan-bahan tersebut adalah tidak mencukupi dan terkini.

Secara keseluruhannya meskipun persepsi pentadbir dan guru terhadap kemudahan prasarana di sekolah menengah harian adalah tidak pasti, namun dapatan soalan tebuka, temubual dan pemerhatian, aspek kemudahan prasarana perlu di nilai, disemak, ditambahbaik secara menyeluruh dan sistematik di sekolah menengah harian agar dapat dimanafaatkan dalam pengajaran dan pembelajaran untuk meningkatkan pencapaian pelajar.

\subsection{CADANGAN}

Peruntukan baru terhadap kekangan kemudahan prasarana seperti bengkel, alatan tangan, alatan mesin, komputer serta bahan bantu mengajar yang kritikal di sekolah menengah harian perlu ditentukan. Bengkel khas yang lengkap dengan peralatan perlulah disediakan sebelum penawaran mata pelajaran dilaksanakan. Proses perbekalan peralatan, penyelenggaraan bengkel, peralatan dan komputer serta pelupusan dan penggantian perlulah sistematik, oleh seseorang yang dilantik dan berkelayakan. Bahan bantu mengajar seperti perisian pembelajaran dan perisisan komputer hendaklah sentiasa dikemaskini dan diperbaharui, Bahan bantu mengajar yang terhad kepada buku teks dan 'CD courseware’ perlulah dipelbagaikan.

Rujukan

Abdul Rahman Arshad. (2007). Unity And Education in Malaysia. Kuala Lumpur: Dewan Bahasa dan Pustaka. Abu Bakar Nordin. (1991). Kurikulum: Perspektif dan Perlaksanaan. Kuala Lumpur: Pustaka Antara.

Ahmad Suhaimi Omar. (2006). Perancangan Sumber Manusia Mahir Dalam Rencah Pertanian Dan Industri Asas Tani. Konvensyen Pendidikan Pertanian Kebangsaan. Anjuran Jabatan Pendidikan Teknikal, KPM. Hotel Eastin, Petaling Jaya, 20-23 Mac. 
Ahmad Zairi Abas. (2002). Permasalahan Pembelajaran Dalam Mata Pelajaran Teknologi Kejuruteraan: Satu Tinjauan Di Sekolah-Sekolah Menengah Dalam Daerah Batang Padang, Perak Tengah dan Hilir Perak. Tesis Sarjana Pendidikan Universiti Teknologi Malaysia.

Alias Mat Saad. (2010). Penilaian Pelaksanaan Kurikulum Pendidikan Islam Politeknik Kementerian Pengajian Tinggi Malaysia. Tesis Dr. Fal. Universiti Kebangsaan Malaysia, Bangi.

Azizah Sharif. (2003). Pelaksanaan Pengajaran Dan Pembelajaran Kontekstual Fizik Dalam Bilik Darjah di Sekolah Menengah Teknik Kajang. Projek Penyelidikan Sarjana Pendidikan. Universiti Kebangsaan Malaysia.

Bahagian Perancangan dan Penyelidikan Dasar Pendidikan. (2006). Kajian Perlaksanaan Mata Pelajaran Lukisan Kejuruteraan dan Teknologi Kejuruteraan di sekolah Menengah Akademik. Ringkasan Eksekutif Kajian-Kajian, Bahagian Perancangan dan Penyelidikan Dasar Pendidikan 2000-2004, 166-175. Putrajaya: Kementarian Pelajaran Malaysia.

Beynon, J. (1997). Physical Facilities For Education: What Planers Need To Know. UNESCO: International Institute For Educational Planning, 18.

Fazidah Mohd. Jaafar. (2002). Persepsi Guru Dan Pelajar Terhadap Pelaksanaan Kaedah Pengajaran Dan Pembelajaran Matematik Secara Kontekstual di Sekolah Menengah Teknik di Negeri Melaka. Projek Penyelidikan Sarjana Pendidikan. Universiti Kebangsaan Malaysia.

Finch, C. R. \& Crunkilton, J. R. (2005). Curriculum Development In Vocational and Technical Education. Boston.

Fulford, C. P. (1993). Can Learning Be More Efficient? Using Compressed Speech Audio Tape To Enhance Systematically Designed Text. Educational Technology, 32 (2): 51-59.

Gay, L.R. \& Airasian, P. (2000). Educational Research: Competencies For Analysis And Application. New Jersey: Prantice-Hall Inc.

Husted, S. W., Mason, R. E. \& Adams, E. (2003). Cooperative Occupational Education Including Internships, Apprenticeships and Tech-Prep. New Jersey: Prentice Hall.

Juraidah Mat Jelani. (2005). Penilaian Rancangan Latihan Mengajar (RLM) program pendidikan guru Universiti Utara Malaysia. Tesis Sarjana Pendidikan. Universiti Kebangsaan Malaysia.

Kementerian Pelajaran Malaysia. (2006). Pelan Induk Pembangunan Pendidikan 2006-2010. Putrajaya: Kementerian Pelajaran Malaysia.

Kementerian Pendidikan Malaysia. (2009). Laporan Tahunan. Kuala Lumpur.

Kementerian Pendidikan Malaysia. (2010). Laporan Tahunan. Kuala Lumpur.

Kementerian Pendidikan Malaysia. (2011). Laporan Tahunan. Kuala Lumpur.

Krejcie, R. V., \& Morgan, D. W. (1970). Determining Sample Size For Research Activities. Educational and Psychological Measurement, 30 : 607-610.

Mohamad Hussin Mohamad Yusof. (2006). Penilaian terhadap Perancangan Dan Pelaksanaan Program Pembelajaran Kontekstual Di Sekolah-Sekolah Menengah Teknik di Malaysia. Tesis Doktor Falsafah. Universiti Kebangsaan Malaysia.

Newman, W. L. (2000). Social Research Methods: Qualitative and Quantitative Approaches. Edisi ke-4. New York: Alyn and Bacon.

Radin Mohd Shamsul Zahril Hirzin. (2008). Penilaian Program Pentaksiran Berasaskan Sekolah Teknologi Kejuruteraan SPM. Tesis Sarjana Pendidikan. Universiti Kebangsaan Malaysia.

Rudzi Munap. (2003). Penilaian Program Diploma Kesetiausahaan Eksekutif di Universiti Teknologi Mara. Tesis Doktor Falsafah. Universiti Kebangsaan Malaysia.

Ruhizan M. Yasin, Ramlee Mustapha, Asnul Dahar Minghat, Kamaruzaman Jusoff, Azaman Ishar \& Shafie Shamsudin. (2012). Pelaksanaan Pengajaran dan Pembelajaran Mata Pelajaran Lukisan Kejuruteraan di Sekolah Menengah. Asia Pacific Journal of Educators and Education, 27, 23-26.

Stufflebeam, D. L, Foley, W. J., Gephart, W. J., Guba, E. G., Hammond, R. L., Merriman, H. O. \& Provus, M. M. (1971). Educational Evaluation And Decision Making. Itasca: F.E. Peacock.

Syed Kamarudin Hj. Sudakhuthulla. (2007). Analisis Kemudahan Pengajaran Dan Pembelajaran Dan Pembelanjaan Kos Pengajian Tinggi Serta Implikasi Terhadap Pencapaian Akademik Pelajar UKM. Tesis Sarjana. Fakulti Pendidikan Universiti Kebangsaan Malaysia, Bangi.

Zakaria Kasim \& Idris Md. Nor. (1995). Latihan mengajar: Permasalahan dan cabaran di Universiti Sains Malaysia. Prosiding Seminar JKLKAU Ke-9, Pendidikan Guru: Cabaran, Falsafah Dan Strategi Dalam Pembentukan Guru Yang Unggul, 113 -118.

Zawawi Ismail. (2008). Penilaian Pelaksanaan Kurikulum Kemahiran Bertutur Bahasa Arab komunikasi di Sekolah Menengah Kebangsaan Agama. Tesis Doktor Falsafah. Universiti Kebangsaan Malaysia, Bangi. 